\title{
The semper reformanda principle under scrutiny in an African context in relation to inculturation
}

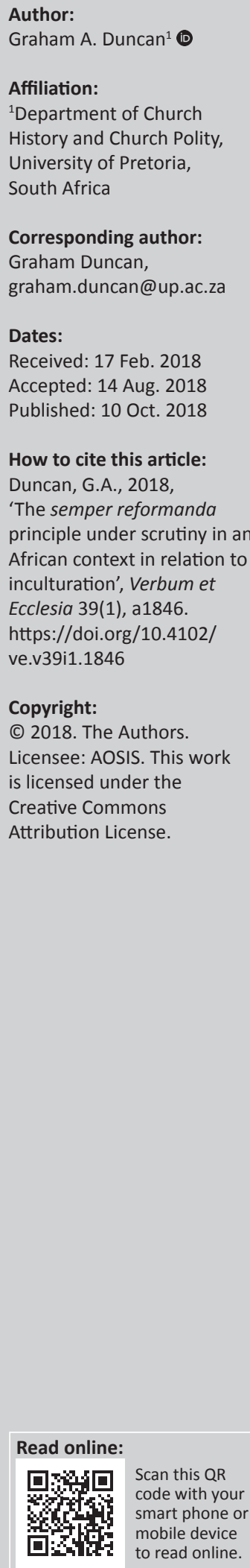

The semper reformanda [always reforming] principle has been poorly promoted by all traditions since it was conceptualised following the 16th-century Reformation. A significant problem caused by the missionary movement was the imposition of a Western-style approach to theology, liturgy and polity with little regard for the cultures that were being invaded and diminished. This article examines the hermeneutical problem in the African context, as well as the concept of and practice of inculturation, and proposes a way forward on the basis of faithfulness to the semper reformanda principle.

Intradisciplinary and/or interdisciplinary implications: This article is interdisciplinary in the sense that it transcends the theological disciplines of Church History, Church Polity, Dogmatics, Practical Theology, African Theology and Missiology. The topic indicates the relevance of an interdisciplinary approach in order to produce an inclusive, integrated and well-rounded approach within the broad field of hermeneutics.

\section{Introduction}

Many extremely serious issues confront both the contemporary church and world. In many cases these issues are confronted and dealt with. However, sometimes, issues that can be considered as adiophora (inconsequential matters) emerge that detract from the more serious issues. Some of these matters have become evident only recently. However, the church has always had a way of responding to contemporary challenges through its commitment to the semper reformanda [always reforming] principle. A significant problem caused by the missionary movement was the imposition of a Western-style approach to theology, liturgy and polity with little regard for the cultures that were being invaded and diminished. This article examines the hermeneutical problem in the African context, with a particular focus on the homosexuality debate, and suggests that the concept of and practice of inculturation and proposes a way forward on the basis of faithfulness to the semper reformanda principle.

\section{Where are we now? African hermeneutics}

First-century Palestine provides the original locus and genesis of contextual theology. During that period, the gospel, still in formation as scripture, was exposed to the Greek and Latin contexts even in North Africa, where significant developments took place through the work of scholars like Origen, Tertullian, Cyprian and Augustine (Bediako 1992:15-222). Throughout, the semper reformanda principle was operative as early theological developments took place. The theologies that emerged from these contexts in contexts of persecution and internal ecclesiastical strife have dominated the world ever since through Western theology and were transferred back into the African context simpliciter after the rise of the 18th-century missionary movement. However, the missionaries perceived African culture negatively and any accommodation of it was regarded as syncretism. In more recent times, this approach has been challenged and modified in the process of inculturation.

The issue of inculturation versus syncretism is an attitudinal one. Syncretism is the result of a blending of Christianity with a local culture to produce what was considered a diluted form of Christianity. It was viewed by the missionaries as a negative process. They wished to exclude any meaningful relationship of the gospel with culture. Inculturation is the derivative of a more positive process of incorporating the gospel into a new host culture to enhance the expression and understanding of both (as will be discussed later). Syncretism is seen as a threat to the gospel, while inculturation considers it an ally. Inculturation may be seen as parallel to the integration that is derived from being 'in Christ' through incorporation ( $\mathrm{Rm}$ 6:3-11). As stated by Chitakure (2017):

... the early missionaries understood syncretism negatively, as the compromising of the Christian faith through its illicit harmonization with the receiving culture. The missionaries forgot that the Christian 
message was not pure from cultural imports. Jesus Christ was born a Jew, and followed the Jewish culture. When he started preaching, he spoke the Jewish language, gathered Jewish disciples, and ate Jewish food. When Christianity spread to other countries, particularly Europe, it was also inculturated into the European culture. (p. 7)

This raises a question regarding the original core message Jesus brought: 'The kingdom of God is at hand; repent and believe the gospel' (Mk 1:15). He brought this message to his own Jewish people clothed in its own cultural and philosophical assumptions and this process has been ongoing ever since. At the time of the 16th-century European Reformation, a number of national confessions of faith were produced that were relevant to their particular contexts. It could be said that the missionaries debunked this approach when they moved beyond the Americas and Europe. They hampered their own work by the approach they adopted to foreign peoples, that of cultural superiority, which led them to impose their perception of the gospel. They preferred to talk before they listened, if they listened at all. Their approach to traditional religion was based largely on ignorance of local cultures as they could not engage with what they did not know or understand (Chitakure 2017):

Their cultural arrogance robbed them of the humility that is a prerequisite to hearing the whispering and ubiquitous voice of God in any given place. Most of them could not resist the proclivity to condemn most African religious, cultural, political, and social practices that were different from their own. (p. 2)

The gospel message that they brought was sometimes indistinguishable from their own cultures, and was offered as a one-way traffic that was intended to transform and domesticate the receiving culture, without allowing itself to be formulated and interpreted anew by that culture. (p. 5)

Like humour, cultural concepts are not easily translatable. Max Warren (1963) expressed the sensitivity that is required when we step into another culture.

Our first task in approaching another people, another culture, is to take off our shoes for the place we are approaching is holy. Else we may find ourselves treading on men's dreams. (p. 10)

Taylor (1963:33) reflects on the insight that the world Church is impoverished and incomplete without the insights that the Logos has been preparing for it'. This is the preparatio evangelica.

The actual problem lay with the imposition of a Western mode of thinking. Derrida and Bass (2002:351-370) suggest that we should deconstruct Westernised thinking, which tends to construct everything in terms of binary opposites, where one term is always given preference over its opposite. Such an approach is a direct contradiction of the cognitive processes of African holistic reflection.

History has proved that it is impossible to adhere to a static approach to biblical interpretation because the discovery of archaeological and documentary evidence from time to time has shed more light both on the text and context in which scripture was formed. If we accept that there can be no further relevant textual or archaeological discoveries, this approach might hold. However, it is difficult to imagine scripture unaffected by the discovery of evidence provided by the Ugaritic Ras Shamra texts and the Qumran Dead Sea Scrolls during the 20th century. Such recent discoveries alter, to a degree, the focus of our interpretive lenses. In Africa, community-oriented religious concepts are more true to the original Palestinian context than individually oriented Western dualistic approaches, which are derived from Greek philosophy; for example, without getting into the merits and demerits of $u b u n t u$, which is one of the most abused concepts in African philosophy and theology, the concept of personhood in African philosophy is more closely related to communion in theological understanding than in Western theology. Here umntu ngumntu ngabantu [a person is a person through other people] expresses participation in a community rather than the creation of community. In Africa, communion is taken as a sine qua non. In baptism, this implies being born into a community as opposed to incorporated into an existing community. In the sacrament of Holy Communion, we see the expression of community rather than the formation of community as was the tendency of Reformed theology exemplified by John Knox (McEwen 1961):

Herewith, also, the Lord Jesus gathers us into one visible body, so that we be members of one another, and make altogether one body, whereof Jesus Christ is the only Head.

This means, if words mean anything, not just that Christ gathers and creates the Church, but that He gathers it by this sacrament, and that on this sacrament He founds it. (pp. 56-57)

The gospel has often been colonised by Western interests through their support (read: funding) manifested by United States bishops and African 'converts' to conservative evangelicalism (cf. 1998 Lambeth Conference) and bribery of African bishops by their American counterparts (Hassett 2007:71-101). The abuse of the Bible is not the prerogative of one group of interpreters. In addition to the broad hermeneutic issue, there are African approaches to hermeneutics (West 2016):

Any analysis of the Bible in African Christianity must also distinguish between 'insider' (emic) perspectives on the Bible and 'outsider' (etic) perspectives. For example, while many African Christianities claim to be 'Bible-based' (an emic claim), analysis of how they actually use the bible by scholars from outside the community (etic analysis) might find that the bible actually plays very little part. The primary focus may in fact be on the Christian tradition of that community, which offers predetermined interpretations of almost any biblical text.

Allowing emic and etic perspectives to interact and engage with each other maybe a useful way forward for our analysis of the role of the bible in African Christianity. (p. 85)

West appears to suggest that differing approaches can be combined, although the conservative evangelical, literalistic and fundamentalist approaches tend to favour exclusion rather than inclusion. This is evident in a recent African publication. 
The Africa Bible commentary (Adeyemo 2006), authored by Evangelical African scholars, states that '[t]he Bible clearly defines homosexuality as a sin' (Turaki 2006:1355). To appreciate the predominant African position, it is important to realise that homosexuality is against the law in most African states and that the responsibility to marry and have children is a very strong expectation, supported by traditional African and biblical world view (Gn 1:28; 9:7). It is also the case that there are passages in the New Testament, especially Romans 1:24-7, that are most straightforwardly understood as condemnations of homosexual practice and orientation. For people who see themselves as inhabiting the world of the Bible, the message seems plain. Furthermore, the actions of the Episcopal Church in the USA seemed to be disrespectful both of the clear message of scripture and also of African views (Kaye 2008:175-195). It is true that Akinola and others disregard scientific and cultural considerations, not to mention the experience of homosexual people - including many African Christians (Brown 2006). However, if there is to be reconciliation on the issue, one of the conditions must be that other Christians make a case on the basis of what is written in the Bible (Kim \& Kim 2016:110). However, Alimi (2015) clearly states that:

In digging up facts I found that, while many Africans say that homosexuality is un-African, African culture is no stranger to homosexual behaviours and acts.

For example, in my local language (Yoruba), the word for 'homosexual' is adofuro, a colloquialism for someone who has anal sex. It might sound insulting and derogatory, however, the point is there is a word for the behaviour. Moreover, this is not a new word; it is as old as the Yoruba culture itself.

In the northern part of Nigeria, yan daudu is a Hausa term to describe effeminate men who are considered to be wives to men. While the Yoruba word might be more about behaviour than identity, this Hausa term is more about identity. You have to look and act like a yan daudu to be called one. It is not an identity you can just carry. These words are neutral; they are not infused with hate or disgust. (p. 1)

One set of assumptions cannot be extrapolated to the general African context simpliciter without interrogating the underlying presumptions (prejudices?) even within the Christian community. The predominant presumption here is that homosexuality is a Western imposition on an otherwise heterosexual continent.

The matter of lawfulness in relation to scripture is problematic. Do we return to the practice of slavery, normalised in scripture but outlawed in the 19th century, to be revamped as human trafficking in the 20th century? It appears that only homophobia, one root of the homosexuality debate, escapes interrogation and condemnation, which is not extended to other prohibited activities such as eating pork and shellfish (Lv 11:7; 11:10). Consequently, we need to ask why we fixate on only one aspect of the Holiness Code? Is there a gradation of prohibitions that makes some more worthy of curses than others? Can we even venture to say that any sexual activity, so long as it occurs between members of different genders, is less obscene than same-sex activity? Further, the few texts from both the Old and New Testaments against what are considered homosexual practices are notoriously difficult to interpret (Römer 2018:215-228). A localised code of conduct (the Holiness Code in the book of Leviticus) given to guide a people in a crisis (e.g. the Exodus, Babylonian exile) is globalised as a one-size-fits-all ethical code. Even today we cannot simply extrapolate scripture from its context, for (Ballard 2011):

... the Bible does not exist independently but embedded, in a peculiar and particular way, within and through the community of faith. ... the implication of the notion of the Bible as Scripture as a serious factor in looking at the use of the bible in pastoral practice has not been, in any systematic way, taken up. (p. 158)

What is often forgotten is that the purpose of the Bible is to be a source of the proclamation of God's loving justice for the world that will stimulate the consciences of God's people to reach out in his mission of reconciliation. The Bible has a source community of origin as well as source communities of transition and destination. It is the relevance of its particularity in its community of origin that enables it to be of general relevance. Here '[c]ontextualisation has more to do with a hermeneutical issue' (Fleming 2005:152). For instance, Allen (1962:12) claims that 'Paul's concentration model of evangelism in particular places was to make local congregations become the centers of light to the world'. It is in the practical domain that the gospel becomes relevant and provides principles, not instructions, for practice. This requires (Ballard 2011):

.. phronesis: practical wisdom. This is the task of a lifetime, acquiring the 'habit' of love, indwelling the word of Scripture as well as living in the concrete reality of our times. This brings us close to the terminology of literary hermeneutics, of the language of 'the merging of the two horizons'.... in the end it is not about skills or information, though both are vital when it comes to working with people, but character. (p. 161)

Here we note the prevalence of a personal and/or communal spiritual approach that people draw closer to the ultimate realities of life. This is problematic for rigid fundamentalists, who need specific solutions for all situations precisely because they do not trust individual 'character', which may be influenced by the humanity of situations confronted. They find security in exclusive rather than inclusive hermeneutics, for they require less risk-taking. Here divine grace may pre-empt human law in order to develop a more human and humanitarian approach that reflects Jesus' pastoral methodology as 'radical humanism' (Küng 1974:31). This contribution to God's mission is characterised by Hans Küng (1974):
By following Jesus Christ
man [sic] in the world of today
can truly humanly live, act, suffer and die;
in happiness and unhappiness, life and death,
sustained by God and helpful to men [sic]. (p. 602)

This explains and affirms the Chalcedonian formula, where Jesus is defined as 'truly God and truly man' (Chalcedonian Creed 451:1). This is the source of Jesus' radical humanism, 
which was fundamental to his pastoral approach. In terms of his scripture, we must remember he worked with the Hebrew Bible, a currently underrated source of guidance. Pastoral care emerges from growth in the disciplines of prayer, study, reflection and service based in a solid yet developing faith in which the Bible provides an empowering resource.

What is evident here is that while maintaining the authority of scripture many other sources of wisdom contribute to our understanding of people in difficulties and how to mobilise support for them. These may also contribute to a more comprehensive understanding of scripture. Thomas Oden's Pastoral theology: Essentials in ministry (1983) is an excellent example of the use of the early fathers in pastoral care. Another example is the manner in which the Church of Scotland's Group Relations Department adopted and adapted Eric Bern's theory and practice of transactional analysis for 'those who care about growth in loving relationships within the Christian community' (Grigor s.a.:i).

One of the issues, as stated by Ballard (2011):

\begin{abstract}
... in contemporary pastoral care is how the authority of the Bible is to be expressed. The tendency is to have some kind of instrumentalist view of the Bible. ... There is ... a kind of gradation from an explicit proclamation of the Gospel to acts of human solidarity but these are all part of the stuff of the universe of which Christ is both Lord and Saviour and in whom all things cohere. (Col 1:15-20)

... there will always be both a sense of given-ness (the Bible is there on the lectern) and a fluidity as the exegetical and illuminative response proceeds. The Scriptures are a sign of unity and diversity as the witness to the Christ who is present in and with the fellowship and to each individually, in each time and place. (p. 163)
\end{abstract}

One common understanding of pastoral care is that the Bible must be specifically introduced into pastoral conversations if it is to be effective. The author can recall his professor of Practical Theology (the late Rev. Prof. Ian PittWatson, University of Aberdeen, 1970-1980) talking of incidents in pastoral care, with 'pastoral conversation passing imperceptibly into prayer', in which the introduction of biblical texts would have been disruptive.

What is necessary is the acceptance of the normativity of scripture alongside a fluidity in interpretation. The issue here is that for theology to be practical theology it has to work in practice and practise. Otherwise scripture loses its authority. It is not a matter of employing a directive (Jay Adams, Competent to Counsel 1986) conservative evangelical approach to scripture through 'applying' scripture to given pastoral issues. The authority does not reside in quoting 'appropriate' texts but in the manner they are used in pastoral care contexts by caregivers, who (Ballard 2011):

saw the Bible primarily as a resource from which they drew their values, perspective and insights into the human condition, and that this remained in the background and was not necessarily made explicit. (p. 163)
One problem is that often the words may obscure the Word and they may be used indiscriminately and even harshly as well as being applied out of context. In much of the work of ministry, ministers are constantly inculturating the scriptural Word in preaching, teaching, pastoral care and community engagement, making the Word an authentic integrating resource for pilgrims on the journey towards the kingdom of God. The core is that (Ballard 2011):

... the Biblical witness, for all its oddity and audacity, is that there is a story of redemption at the centre of which is the living Christ. But it is not a story that is imposed by force but on one that is offered in compassion and love. We are invited to join our story to God's story ... in order to be incorporated into the risen life of Christ, anticipating the gathering together of all things. (p. 164)

From this, it is clear that an instrumentalist approach is inadequate in many ministers' practice. That is, it does not work for them or for those to whom they minister. This is not a novel development as some might suggest. It has a long and distinguished history and is a well-founded tradition. For instance (Ballard 2011):

In Judaism there is a history of interpretation - midrash - which seeks to uncover the deeper meaning of Scripture and its import for living in the present. From this Rabbinic tradition there emerged the Mishnah (the oral teaching) and the Talmud, which combines the Mishnah with further discussions on the Mishnah, called the Gamara. For Scripture to keep its relevance in later and often radically different circumstances there has to be a process of reflection. (p. 166)

The key to this process is dynamism. It has never been static but operated in time, place and humanly specific contexts. The process of discerning Christian truth is ongoing and progressive. It emerges in faithful living, which involves decision, repentance and new steps forward, and sometimes backward, in faith as was the case in the early Christian community, where under severe threat and trauma, the Christian community suffered, endured and grew in numbers and in faith. Focused on the coming kingdom, their hope sustained them. This is a process of lifelong learning, of negotiation through the complexities of living as we attempt to remain loyal to Christ (Ballard 2011):

... we have to live in the mess that is the world and the church. What is being sought, however, is the ability to be true to the fundamental reality of Christ while seeking to embody that truth in and for our time. The result will never be perfect because the Kingdom is not yet here, but we must each work for kingdom values as we can and where we are. (p. 168)

Perfection, like salvation, is not a given; it is something that has to be worked towards as part of life's struggle, although that work has to demonstrate a high degree of authenticity and integrity in the light of our vision and mission. One of the most common criticisms made against the church is its perceived hypocrisy, for example, talking about unity when we actually foster division. What is credible about a church that is polarised and divided within itself (Corrie 2016:193)? The focus is Christ, the Word of God incarnate. Christ was the 
focus before there was scripture to rely on in the same way that there was tradition before the commission of the gospel to writing. Corrie is pointing to issues that the church eschews, for its actions do not reflect its proclamation and marginalise Christ (2016):

... in relation to our interpretation of scripture there is an intrinsic tension between the absoluteness of the text and its contextuality. ... Brueggemann [1997:7] gives due deference to the authority of the text, but at the same time recognises that we are interpreting it in a postmodern context which has no problem with contradiction and ambiguity. (pp. 194-195)

This position is rejected by conservative scholars who cannot consider other interpretations than their own. They do not consider the possibility of living in the midst of tensions and working through them towards new and fresh insights. For them scripture and its interpretation must reflect a static, ahistorical set of instructions, yet our church orders reflect complex developments of the Decalogue, which was sufficient for the people of God in a state of transition. It raises the question, what do we need as we journey on our pilgrimage towards the kingdom of God? Corrie 2016 states:

The problem arises when we believe that the opposite polarity to our own is simply wrong, or does not even exist, in which case it is tempting simply to hold our ground and let the other end go off in its own direction. Once we allow the tension to exist, it will be uncomfortable, but by letting go of the tension we are losing the possibility of a new way of approaching the polarity. (p. 195)

However, living in a situation devoid of tension is not realistic. This was foreign to Jesus' ministry and he actually courted conflict with all its attendant tension in order to promote God's will (e.g. Mk 2-3). Within these uncomfortable situations, he managed to move beyond the Torah by fulfilling its promises and demands. This is the type of reflective and active theology that David Bosch promoted as integral to our participation in God's mission (Bosch 1991):

I would like to posit my belief that we are in need of a theology of creative tension, which reaches beyond the sterile alternative between a comfortable claim to absoluteness and arbitrary pluralism (p. 483) ... [because] It is only within the force field of apparent opposites that we shall begin to appreciate a way of theologising for our own time in a meaningful way. (p. 367)

Bosch was very clear that we live in a time when absolutes of any kind are inappropriate and that this does not accommodate paradox. He was equally clear that we live in the interregnum and not the end time (Bosch 1991):

We do not have all the answers and are prepared to live within the framework of penultimate knowledge. We regard our involvement in dialogue and mission as an adventure (in which) we are prepared to take risks and are anticipating surprises as the Spirit guides us into fuller understanding. This is not opting for agnosticism, but for humility - or a humble boldness. We know only in part, but we do know. And we know that the faith we possess is both true, and just, and should be proclaimed. (p. 489)
Dialogue, not condemnation or ridicule, is God's manner of operation. This is linked to the hospitality that we offer to the other person's views in dialogue. There has to be an openness to allow the other to express their convictions and ask questions about ours without judgment or condemnation, whatever our own views. Without this open form of communication, little or no authentic communication can take place regarding crucial issues, nor can the gospel be proclaimed to willing recipients. This implies working with the values of humility and vulnerability. It might be said that dialogue is God's methodology. Through this approach, the prophetic voice emerges as we earn the right to engage, and that can only happen within a relationship of mutual trust and listening for and to the voice of God as a voice of faith, hope and love. Of course, this may lead God into the realm of challenge, judgement and condemnation. However, these negative approaches constitute the very methodology the missionaries introduced at the opposite end of the spectrum from God, when they introduced the gospel during the past three centuries in many and varied contexts of mission. It is only by taking account of context in a more concrete manner that we can profit from some of the benefits of inculturation as a means to consolidate both culture and mission.

\section{Inculturation}

In this section, consideration will be given to the idea that the process of inculturation is an expression of the semper reformanda principle in action within dynamic African societies, as well as other societies. Historically, Christian missionaries have failed to understand and take account of the spiritual realm of traditional religion in the form of 'primal religion' which encompasses 'the universal, basic elements of man's understanding of God and the world ... by the emergence of a basic world-view which fundamentally is everywhere the same' (Taylor 1963:26-27). Nor had the missionaries come to terms with the supernatural world view of the Bible (Moscicke 2017:127). This is the result of their failure to adopt a holistic view of the cosmos, which they debunked in favour of a historically grounded Western dualistic approach. Akrong (2001:18) emphasises this: 'the dualistic strategy that the missionaries ... used to distinguish Christianity from traditional religion promoted the tendency towards dualism in African Christianity' in the manner in which African and Pietist 'imaginations' were fused. As the result of investigating the cosmologies of African traditional religion (ATR) and African Christianity, Moscicke (2017) concludes that:

... an approach to Scripture that takes seriously its supernatural worldview and its mythological narratives possesses far greater potential for reconciling the spirit world of ATR in African Christianity than the thin, rigid cosmic dualism of the early missionaries. (p. 139)

Such an approach to find common values can yield new means to inculturate Christianity into the African context. The inculturation process can only be undertaken where there is already comprehension of the local culture as it relates to world views, ways of thinking, group solidarity, 
understanding of history and of modernity and its impact (Yung 2014:64-76).

One of the foremost scholars in the field of inculturation is the late Xolile Keteyi, who used inculturation as a relevant approach to evangelisation as the 'evangelisation of culture'. He talked about the evangelisation done by conservatives as that which 'takes no notice of culture' (Keteyi 1998:9). Following on thinking that became normative during Vatican II, Keteyi (1998) defines inculturation as 'an approach to evangelisation that seeks to find a home for Christian faith in the different cultures and an accommodation of cultures in the Christian community'. Quoting Evangelii Nuntiandi (1975), inculturation refers to evangelising:

... in a vital way, in depth and right to their roots, in the wide and rich sense which these terms have in Gaudium et Spes [Flannery 1975:903-1001], always taking the person as one's starting point and always coming back to the relationships of people among themselves and with God.

God spoke according to the culture proper to each age. Similarly the Church has existed through the centuries in varying circumstances and has utilized the resources of different cultures in its preaching to spread and explain the message of Christ, to examine and understand it more deeply.

Nevertheless, the Church has been sent to all ages and nations and, therefore, it is not tied exclusively and indissolubly to any race or nation, to any one particular way of life, or to any customary practices, ancient or modern. ...

The Church ... enter into communion with different forms of culture, thereby enriching both itself and the cultures themselves....

... the Church carries out its mission and in that very act it stimulates and advances human and civil culture ... [Gaudium et Spes, §58, Flannery 1975:962-963]

20. All this could he expressed in the following words: what matters is to evangelize man's culture and cultures (not in a purely decorative way, as it were, by applying a thin veneer, but in a vital way, in depth and right to their very roots), in the wide and rich sense which these terms have in Gaudium et Spes,[\$50] always taking the person as one's starting-point and always coming back to the relationships of people among themselves and with God.

The Gospel, and therefore evangelisation, are certainly not identical with culture, and they are independent in regard to all cultures. Nevertheless, the kingdom which the Gospel proclaims is lived by men who are profoundly linked to a culture, and the building up of the kingdom cannot avoid borrowing the elements of human culture or cultures. Though independent of cultures, the Gospel and evangelisation are not necessarily incompatible with them; rather they are capable of permeating them all without becoming subject to any one of them.

The split between the Gospel and culture is without a doubt the drama of our time, just as it was of other times. Therefore, every effort must be made to ensure a full evangelisation of culture, or more correctly of cultures. They have to be regenerated by an encounter with the Gospel. But this encounter will not take place if the Gospel is not proclaimed. (\$20)

The process depends on mutual influence. The benefit is clear: 'culture continues to develop according to the gospel and its best values are confirmed by the gospel' (Keteyi 1998:37). However, the process is more complex because it has two sides - insertion of the gospel in a new culture and appropriation of the gospel through culture. Bosch (1991:454) has summarised this well: '[I]nculturation suggests a double movement: there is at once inculturation of Christianity and Christianisation of culture' (cf. Forsyth 2017:217). A helpful analogy is drawn between inculturation and the Christian history of salvation (Keteyi 1998):

The history of Israel was a preparation for the eventual selfrevelation of God in human form. In fact the Israelites blended their own theology with the myths and theologies of the people of the Middle East. Their history is a development of a cultural context within which God would eventually appear. (p. 39)

The entire process of inculturation in the apostolic church was akin to the semper reformanda principle as it developed through cultural encounters. This was not primarily the role of missionaries, but (Keteyi 1998):

it belongs to those whose culture and setting raise questions which must be answered though an inculturated faith. It has to be insisted that the answers are what will make them understand and live the gospel with joy. (p. 40)

The challenge of inculturation and semper reformanda are that indigenous peoples must be allowed and encouraged to experience Christianity in a fresh and dynamic way. They must be subjects rather than objects in the process of mutual appreciation, of solidarity between culture and gospel (Keteyi 1998):

... inculturation is a dialogue between living faith and living culture. ... In the encounter ... there will be different outcomes. The test though will be the way in which they inform the life of the people concerned. (p. 41)

In a sense, the heresies of the early church were issues of inculturation, as in the development of monophysitism with the Ethiopian Orthodox Church.

In our own time we can see here the relationship with liberation theology, which is also a product of inculturation and semper reformanda because each require a reading of the times, which along with social analysis needs us to formulate a theological response. Keteyi (1998) states:

The collective memory of the people of the time when there was freedom and justice, combined with the memory of Jesus Christ who brought the message of liberation to humanity, produced an inculturated theology of liberation. (p. 54)

This challenge did not disappear in South Africa with the coming of democracy. Maluleke (1998) urges us to face reality:

... there will be no Africanisation, no $u b u n t u$, no rainbow nation, no nation unless culture and inculturation issues are confronted and dealt with as part and parcel of the material issues facing South Africa today. (pp. 66-67)

However, we need to recognise that inculturation is not only a non-European matter. An example is to be found in 
Forsyth's (2017) study of Reformed Christianity in Scotland from the mid-20th century. He refers to the process of contextualisation in the missionary encounter, no matter its location, 'which seeks to strip away the cultural baggage of the donor in mission to allow the Gospel to be fully heard and connect deeply with the local context' (Forsyth 2017:15). Sunquist (2013) takes this further after affirming that contextualisation and inculturation emerged from within the lived experience of a community of faith:

Outsiders can and should be able to dialogue about what is appropriate, but God's Spirit is more than [being] able to guide the local Christian community without outsiders imposing what may well be the exact opposite of what they are trying to promote. (p. 256)

Then Heard (2013:77) reminds us that 'the Christian faith is never transmitted in a culture-free or culture-neutral cocoon; it needs to be incarnated in the heart of each culture'. This indicates that it has to engage with the esse of each culture. The dilemma that is posed for the Christian missionary is does our faith touch and transform the deepest need of the person we approach with a view to conversion?

\section{A way forward}

There can only be progress on matters of theological interpretation by operating from a perspective of mutual respect and regard, and in solidarity with the gospel. The gospel is not theology but is a source of theology that provides a way of systematising our belief and operates to assist us in deeper understanding of the Good News of Jesus Christ. As the world looks on with amazement at our conflicts in this regard, we should be shamed into creating and affirming solidarity for the sake of the gospel. This can only have its source in God's love and our love for others - agape - a going out of and from the self in the service of others; by contrast, Tillich's definition of love is the 'drive towards the unity of the separated' (Tillich 1954:50). Hence, the need for the principle of semper reformanda.

\section{Conclusion}

Inculturation is a process that has been in process since the genesis of the Christian community. As the gospel spread geographically and was encountered by different peoples and cultures, the semper reformanda principle was operative. The focus on homosexuality in the African context is both topical and prurient compared with other issues of greater significance facing the continent. Our examination of the concept of semper reformanda in the context of inculturation in Africa has been grounded in faithfulness to the past and what we have gained from it in service of the gospel in the present and for the future. The process of inculturation was introduced to remind us that from its inception, the church has inculturated the gospel into the contexts in which it carried out its mission, despite attempts to impose it in its Western discourse. This became static until the rise of contextual theologies in the 20th century, which revealed for us the possibilities of discerning the gospel afresh in the contexts and cultures in which it was proclaimed.

\section{Acknowledgements Competing interests}

The author declares that he has no financial or personal relationships that may have inappropriately influenced him in writing this article.

\section{References}

Adams, J., 1986 (1970), Competent to counsel: Introduction to nouthetic counselling, Zondervan, New York.

Adeyemo, T. (ed.), 2006, Africa Bible commentary, Zondervan, Nairobi.

Alimi, B., 2015, 'If you say being gay is not African, you don't know your history', viewed 17 June 2016, from https://www.theguardian.com/commentisfree/2015/ sep/09/being-gay

Akrong, A., 2001, 'Towards a theology of evil spirits and witches', Journal of African Christian Thought 4(1), 18-21.

Allen, R., 1962, Missionary methods: St Paul's or ours?, Eerdmans, Grand Rapids, MI.

Ballard, P., 2011, 'The scriptures in the church and pastoral practice', in D.E. Singh \& B. Farr (eds.), Christianity and education: Shaping Christian thinking in context, pp. 157-169, Regnum, Oxford

Bediako, K., 1992, Theology and identity: The impact of culture upon Christian thought in the second century and in modern Africa, Regnum, Oxford.

Bosch, D.J., 1991, Transforming mission: Paradigm shifts in the theology of mission, Orbis, Maryknoll, NY.

Brown, T., 2006, 'Introduction', in T. Brown (ed.), Other voices, other worlds, pp. i-xv, Darton, Longman \& Todd, London.

Brueggemann, W., 1997, 'Biblical theology appropriately postmodern', Biblical Theology Bulletin 27(1), 1-10. https://doi.org/10.1177/014610799702700102

Chalcedonian Creed, 451, viewed 16 June 2018, from https://carm.org/christianity/ creeds-and-confessions/chalcedonian-creed-451-ad

Chitakure, J., 2017, African traditional religion encounters Christianity: The resilience of a demonized religion, Pickwick, Eugene, OR.

Corrie, J., 2016, 'Creative tension in mission: Bosch 25 years on', Missionalia 44(2), 192-204. https://doi.org/10.7832/44-2-147

Derrida, J. \& Bass, A., 2002, Writing and difference, University of Chicago Press, Chicago, IL.

Evangelii Nuntiandi, 1975, Evangelii Nuntiandi: APOSTOLIC EXHORTATION OF HIS HOLINESS POPE PAUL VI, Libreria Editrice Vaticana, viewed 28 September 2018 from http://w2.vatican.va/content/paul-vi/en/apost_exhortations/documents/ hf_p-vi_exh_19751208_evangelii-nuntiandi.html

Flannery, A., 1975, Vatican Council II, vol 1: The conciliar and postconciliar documents, Costello, New York.

Fleming, D., 2005, Contextualisation in the New Testament: Pattern for theology and mission, Intervarsity Press, Downer's Grove, IL.

Forsyth, A., 2017, Mission by the people: Re-discovering the dynamic missiology of Tom Allan and his Scottish contemporaries, Wipf \& Stock, Eugene, OR.

Grigor, J.C., s.a., A tool for Christians, Church of Scotland Social Responsibility Committee, Edinburgh.

Hassett, M.K., 2007, Anglican Communion in crisis: How episcopal dissidents and their African allies are reshaping Anglicanism, Princeton University Press, Princeton, NJ.

Heard, J., 2013, 'Inculturation - Faithful to the past: Open to the future', in J. Gittoes, B. Green \&J. Heard (eds.), Generous ecclesiology: Church, world and the kingdom of God, pp. 61-77, SCM, London.

Kaye, B., 2008, An introduction to world Anglicanism, Cambridge University Press, Cambridge.

Keteyi, X., 1998, Inculturation: A strategy for liberation, Cluster, Pietermaritzburg.

Kim, S. \& Kim, K., 2016, Christianity as a world religion: An introduction, 2nd edn., Bloomsbury, London.

Küng, H., 1974, On being a Christian, Collins, Glasgow.

Maluleke, T.S., 1998, 'Epilogue', in X. Keteyi (ed.), Inculturation: A strategy for liberation, pp. 61-67, Cluster Publications, Pietermaritzburg.

McEwen, J.S., 1961, The faith of John Knox, Lutterworth, London.

Moscicke, H., 2017, 'Reconciling the supernatural worldviews of the Bible, African traditional religion and African Christianity', Missionalia 45(2), 127-143.

Oden, T.C., 1983, Pastoral theology: Essentials in ministry, Haroer \& Row, San Francisco, CA. 
Römer, T., 2018, 'Homosexuality in the Hebrew bible: Some thoughts on Leviticus 18 \& 20 and the David-Jonathan narrative', in M. Oeming (ed.), Avahah: Die Liebe Gottes im alten Testament, pp. 215-228, Evangelische Verlagsanstalt, Leipzig. Sunquist, S.W., 2013, Understanding Christian mission: Participation in suffering and glory, Baker, Grand Rapids, MI.

Taylor, J.V., 1963, The primal vision: Christian presence amid African religion, SCM London.

Tillich, P., 1954, Love, power, and justice: Ontological analysis and ethical applications, Oxford University Press, Oxford.
Turaki, Y., 2006, 'Homosexuality', in T. Adeyemo (ed.), Africa Bible commentary, p. 1355 , Zondervan, Nairobi.

Warren, M.A.C., 1963, 'Introduction', in J.V. Taylor (ed.), The primal vision: Christian presence amid African religion, pp. 5-12, SCM, London.

West, G., 2016, 'The role of the Bible in African Christianity', in I.A. Phiri, D. Werner, C. Kaunda \& K. Owino (eds.), Anthology of African Christianity, pp. 76-88, World Council of Churches, Geneva.

Yung, H., 2014, Mangoes or bananas: The quest for an authentic Asian theology, Oxford Centre for Mission Studies, Oxford. 